\title{
Notes and News
}

Offprints of 'Notes and News' are available on a subscription basis as from January 1966 . They are printed on one side of the paper only. The annual subscription is $75 \mathrm{P}\left(\$ 2.00 ; F_{11}\right)$, post free.

\section{Aberdeen University African Studies Group: Colloquium on Senegambia}

A colloquium on Senegambia was held at the University of Aberdeen from 3 to 5 April I974.

A public lecture was given by Professor Yves Person (CNRS, Paris) and the papers read included the following: Professor J. D. Hargreaves: 'Senegambia: some historical perspectives'; Dr. Adrian Adams: 'Senegalese migrant labour in France'; Mr. A. Hughes: 'Gambian perceptions of Senegambian integration.'

The two main topics considered were: Unity and diversity of Senegambia and prospects for co-operation.

\section{African Studies Association in Switzerland}

Iv February this year an African Studies Association (Schweizerische Afrika Gesellschaft Société Suisse d'Études Africaines) was founded in Switzerland. Its objectives are the fostering and co-ordinating of inter-disciplinary research, documentation and information on Africa. Scientific meetings will be organized, research projects discussed, and a year-book published. Among its principal activities will be co-operation with similar Institutions in Switzerland and abroad and with development Agencies.

Dr. Hugo Huber, Professor of Ethnology at the University of Fribourg, has been elected as its first President.

The Association's Secretariat is at Geneva. Its address is: Professor Pierre Bungener, c/o Institut d'Études du Développement, 24 Rue Rothschild, Ch-1202 Genève.

\section{Society for Applied Anthropology: Meetings in Holland 1975}

THE Society for Applied Anthropology plans to hold its 34th annual meeting at the Royal Tropical Institute, Amsterdam, from I9 to 22 March 1975. The deadline for abstracts of symposia and volunteered papers is is September 1974 .

The Program Chairperson (American) is Vera Green, Department of Anthropology, Livingstone College, Rutgers University, New Brunswick, New Jersey 08903. The Program Chairperson (European) is Henri Claessen, Institut voor Culturele Antropologie en Sociologie der Niet-Westerse, Volken, Stationsplein Io, Leiden, Holland.

\section{Standing Conference on Library Materials on Africa: Publications}

SCOLMA have recently published the following titles:

U.K. Publications and Theses on Africa, 1967/68, compiled by Miriam Alman. London: Frank Cass, July 1973. $£ 2 \cdot 50$ paper, $£ .3 .50$ hardback.

SCOLMA Directory of Libraries and Special Collections, compiled by Robert Collison and revised by John Roe. London: Crosby Lockwood Staples, August 1973. £2.95.

Printing and Publishing in Kenya: an Outline of Development, by John Ndegwa. London: SCOLMA, 1973. sop. 